\title{
Sistem peradilan adat dalam kesatuan-kesatuan masyarakat hukum adat desa pakraman di Bali
}

\author{
I Ketut Sudantra, Tjok Istri Putra Astiti, \\ I Gusti Ngurah Dharma Laksana \\ Universitas Udayana \\ Email: sudantra01@yahoo.co.id
}

\begin{abstract}
Abstrak
Artikel ini bertujuan untuk mengungkapkan eksistensi sistem peradilan adat dalam kesatuan-kesatuan masyarakat hukum adat desa pakraman di Bali, baik menyangkut aspek kelembagaannya, hukum yang dijadikan dasar dalam mengadili, wewenang atau kompetensinya, serta mekanisme kerja peradilan adat di dalam kenyataannya. Kajian diawali dengan mengungkap aspek normatif dari sistem peradilan adat menurut peraturan hukum (awigawig) yang berlaku, selanjutnya dikonfirmasi secara empiris untuk dapat mengetahui dan menjelaskan sistem peradilan adat yang hidup di dalam kenyataannya. Hasil kajian menunjukkan bahwa peradilan adat adalah suatu fakta empiris yang nyata-nyata dipraktikkan dalam kesatuankesatuan masyarakat hukum adat desa pakraman di Bali. Kelembagaan yang melaksanakan fungsi peradilan adat di desa pakraman (kertha desa) adalah kepala-kepala adat (prajuru) bersama dengan elemen-elemen kelembagaan desa lain yang ada di desa pakraman (paduluan, kepala dusun/kepala desa). Mereka melakukan proses peradilan berdasarkan hukum adat dan berwenang mengadili semua perkara yang diajukan kepadanya, baik yang berupa sengketa maupun pelanggaran hukum. Peradilan adat menyelesaikan setiap perkara yang diajukan kepadanya melalui mekanisme musyawarah mufakat dalam suatu pertemuan yang disebut paruman prajuru.
\end{abstract}

Kata kunci: peradilan adat, kertha desa, kesatuan masyarakat hukum adat, desa pakraman.

\footnotetext{
Abstract

This article aims to reveal the existence of customary court system on the customary law society entities of desa pakraman in Bali, both related to its institutional aspect, the kind of law its judgement was based, its authority or competency,
} 
and its work mechanism on reality. The study begins with revealing the normative aspect of customary court system according to applied regulation (awig-awig), which then empirically confirmed to affirm and explain the customary court system that lives on reality. Study's result shows that customary court is an empiric fact that trully practiced on customary law society entities of desa pakraman in Bali. The institution that executing function in desa pakraman (Kertha Desa) is customary chiefs (prajuru) together with other village institution elements in desa pakraman (paduluan, kepala dusun/kepala desa). They execute court procession based on customary law and have authority to judge all case submitted to them, both in form of dispute or violation of regulation. Customary court settle every case submitted through a deliberation mechanism in a meeting named Paruman Prajuru

Key words: customary court, kertha desa, customary law society entities, desa pakraman

\section{Pendahuluan}

Secara yuridis, eksistensi peradilan adat diakui oleh Negara Smelalui Pasal 18B ayat (2) Undang-Undang Dasar Negara Republik Indonesia Tahun 1945, tetapi hingga saat ini pengakuan tersebut belum diderivasike dalam peraturan perundang-undangan di bawah undang-undang dasar (Sudantra, 2016:306), kecuali peradilan adat di Provinsi Papua telah diakui melalui Undangundang Nomor 21 Tahun 2001 tentang Otonomi Khusus Bagi Papua (Jamin, 2014:369; Krisifu, 2014:17). Perjuangan untuk pengakuan yuridis terhadap eksistensi peradilan adat secara nasional telah dilakukan banyak pihak, antara lain oleh Aliansi Masyarakat Adat Nusantara (AMAN) dan berbagai Lembaga Swadaya Masyarakat (LSM). Hasil perjuangan tersebut sudah sampai pada tahapan masuknya pasal tentang pengakuan terhadap eksistensi peradilan adat dalam Rancangan Undang-undang tentang Pengakuan dan Perlindungan Hak Masyarakat Hukum Adat (RUU-PPHMHA) yang disiapkan oleh Badan Legislasi (Baleg) Dewan Perwakilan Rakyat Republik Indonesia (DPR-RI) tahun 2012. RUU tersebut sampai sekarang masih berproses di DPR-RI dan dalam perkembangan terakhir masuk menjadi Pogram Legislasi Nasional 
(Prolegnas) Prioritas 2017 (http://www.dpr.go.id/uu/prolegnas).

Proses pembentukan peraturan perundang-undangan sangat membutuhkan masukan dari masyarakat dan pemangku kepentingan, termasuk dari kalangan perguruan tinggi, agar materi muatan undang-undang tersebut dapat memenuhi aspirasi dan kebutuhan hukum masyarakat. Dalam proses pembahasan RUU-PPHMHA, sumbangan yang dapat diberikan oleh kalangan akademisi dari perguruan tinggi adalah hasil-hasil penelitian yang relevan dengan materi muatan undang-undang tersebut. Salah satu materi muatan RUU-PPHMHA adalah pengakuan terhadap eksistensi peradilan adat di Indonesia, sehingga dalam proses pembahasannya, pembentuk undang-undang (legislatif) sangat membutuhkan pengetahuan dan pemahaman yang memadai tentang kondisi riil bangunan peradilan adat yang masih hidup dalam kesatuan-kesatuan masyarakat hukum adat di seluruh wilayah Indonesia, termasuk Bali. Itulah sebabnya, sangat urgen dilakukan penelitian mengenai eksistensi peradilan adat dalam kesatuan masyarakat hukum adat desa pakraman di Bali untuk menjawab kebutuhan pembentuk undang-undang, khususnya dalam pembahasan RUU-PPHMHA.

Sebelumnya, Sudantra dan Sukerti (2014) telah melakukan penelitian pendahuluan mengenai pengaturan peradilan adat dalam awig-awig desa pakraman di Bali. Hasil penelitian menunjukkan bahwa secara normatif peradilan adat diakui eksistensinya dalam awig-awig desa pakraman. Awig-awig adalah peraturan yang dibuat oleh kesatuan-kesatuan masyarakat hukum adat di Bali, berlaku internal bagi kesatuan-kesatuan yang bersangkutan. Salah satu rekomendasi dari hasil penelitian tersebut adalah perlunya penelitian dilanjutkan dengan penelitian hukum empris untuk mengetahui eksistensi peradilan adat di dalam kenyataannya, sebagaimana dipraktikkan dalam kesatuan-kesatuan masyarakat hukum adat desa pakraman di Bali (Sudantra dan Sukerti, 2014:316).

Tulisan ini adalah hasil penelitian yang dapat dipandang sebagai kelanjutan dari penelitian tersebut. Tujuannya adalah untuk mengungkapkan kondisi empiris eksistensi peradilan adat yang masih hidup dalam kesatuan masyarakat hukum adat desa pakraman di Bali, baik mengenai konsepnya, kelembagaan yang melaksanakan fungsi peradilan adat, hukum yang dijadikan dasar dalam mengadili dan menyelesaikan perkara, serta 
kewewenangnya, serta mekanisme kerja dari peradilan adat dalam mengadili dan menyelesaikan perkara yang dihadapinya.

\section{Konsep peradilan adat}

Peraturan perundang-undangan yang secara ekplisit menyebutkan istilah dan menjelaskan konsep peradilan adat adalah UndangUndang Nomor 21 Tahun 2001 tentang Otonomi Khusus Bagi Papua. Undang-undang ini menegaskan pengakuan dan penghormatan negara terhadap eksistensi peradilan adat di bumi Papua. Menurut Pasal 51 ayat (1) undang-undang tersebut, peradilan adat adalah peradilan perdamaian di lingkungan masyarakat hukum adat, yang mempunyai kewenangan memeriksa dan mengadili sengketa perdata adat dan perkara pidana di antara para warga masyarakat hukum adat yang bersangkutan. Selanjutnya dalam ayat (2) dan ayat (3) ditentukan bahwa Pengadilan adat disusun menurut ketentuan hukum adat masyarakat hukum adat yang bersangkutan; mempunyai kewenangan memeriksa dan mengadili sengketa perdata adat dan perkara pidana berdasarkan hukum adat masyarakat hukum adat yang bersangkutan. Selain dalam Undang-undang Nomor 21 Tahun 2001, istilah peradilan adat juga ditemukan dalam penjelasan terhadap Pasal 9 ayat (1) Undang-undang Nomor 18 Tahun 2004 tentang Perkebunan, yang menjelaskan bahwa keberadaan peradilan adat merupakan salah satu indikator yang menunjukkan bahwa suatu kesatuan masyarakat hukum adat masih ada di dalam kenyataannya.

Dengan menarik unsur-unsur Pasal 51 Undang-undang Nomor 21 Tahun 2001 di atas, Sudantra (2016:40) menguraikan konsep peradilan adat tersebut sebagai berikut:

1. Peradilan adat adalah sistem peradilan yang hidup dalam kesatuan-kesatuan masyarakat hukum adat di Indonesia;

2. Peradilan adat berdasarkan pada hukum adat;

3. Peradilan adat bukan merupakan bagian dari sistem peradilan negara;

4. Peradilan adat berwenang mengadili perkara-perkara adat, baik yang berupa sengketa maupun pelanggaran hukum adat;

5. Peradilan adat berwenang mengadili perkara-perkara antara warga kesatuan masyarakat hukum adat. 


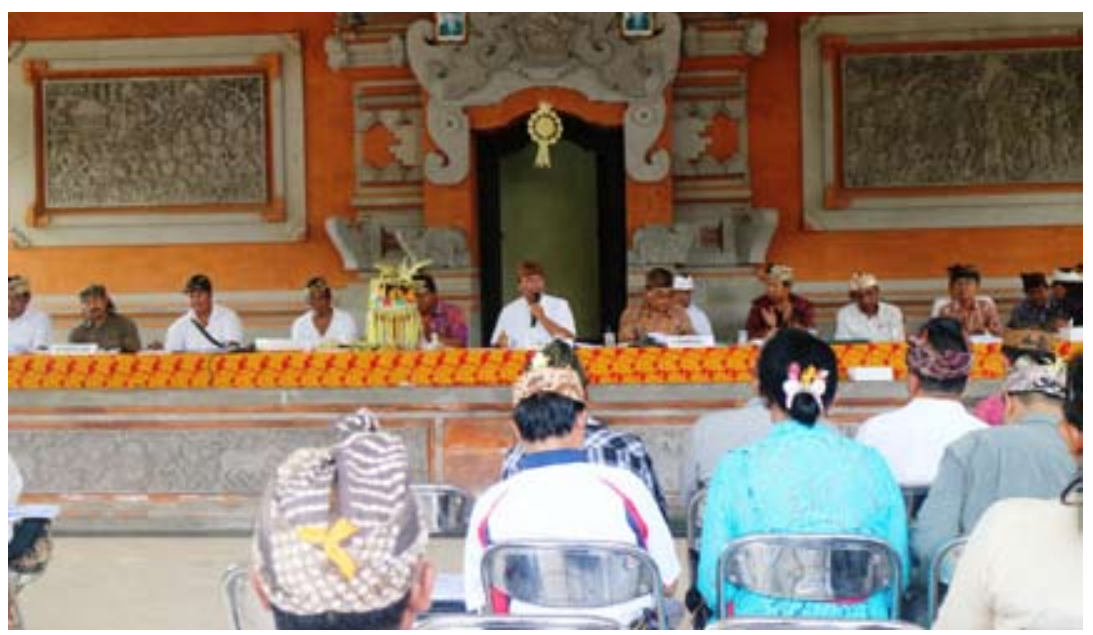

Foto 1. Suasana rapat sebuah desa pakraman di Denpasar. Dalam forum seperti ini awig dan masalah desa dibahas (Foto Darma Putra).

Secara sosiologis, istilah peradilan adat bukanlah istilah yang lazim digunakan dalam kehidupan masyarakat sehari-hari, bahkan istilah "peradilan adat" hampir tidak pernah digunakan dalam pergaulan masyarakat. Walaupun istilah "peradilan adat" tidak pernah digunakan dalam bahasa sehari-hari dari masyarakat, tetapi para peneliti pada umumnya percaya bahwa semua kesatuankesatuan masyarakat hukum adat di Indonesia mempunyai suatu sistem atau mekanisme penyelesaian masalah yang dapat dipahami sebagai sistem peradilan sesuai konsep di atas. Istilah-istilah yang digunakan sangatlah beragam, seperti "sidang adat", "rapat adat" dan lain-lain (Anonim 2003:8; Utama \& Aristya, 2015:62)

Kondisi seperti itu juga berlaku dalam kesatuan-kesatuan masyarakathukum adatdesa pakraman di Bali.Dewasa ini, sebagian besar desa pakraman di Bali telah mempunyai awig-awig tertulis sebagai pedoman dalam menyelenggarakan kehidupan sosialreligius masyarakatnya. Walaupun tidak ditemukan satu pun awigawig desa pakraman yang menyebutkan istilah "peradilan adat" di dalam pasal-pasalnya (pawos), namun awig-awig desa pakraman dengan jelas mengatur mekanisme penyelesaian masalah-masalah hukum yang terjadi di lingkungan desa pakraman, yang secara teknis awig-awig disebut dengan istilah wicara (Ind.: masalah/ perkara). Mekanisme tersebut diatur dalam bab (sarga/sargah) 
tersendiri dalam awig-awig, yaitu dalam bab yang berjudul Wicara lan Pamidanda (Ind.: Perkara dan Sanksi), Dalam bab ini ditentukan mengenai lembaga yang berwenang menyelesaikan perkara di desa pakraman, tata-cara penyelesaiannya, dan bentuk-bentuk sanksi yang dapat dijatuhkan kepada pihak yang dinyatakan terbukti melakukan kesalahan atau pelanggaran hukum.

Dalam beberapa awig-awig yang diteliti, pada bab Wicara lan Pamidanda ini ditemukan istilah "kertha desa", yang secara spesifik dapat dimaknai sebagai lembaga yang melaksanakan fungsi peradilan adat. Namun, hasil penelitian lapangan menunjukkan bahwa istilah "kertha desa" bukanlah istilah yang merakyat. Dalam bahasa sehari-hari, masyarakat menyebut mekanisme penyelesaian perkara tersebut dengan istilah yang beragam dan cendrung bermakna umum, tidak secara spesifik mewakili konsep peradilan adat. Apabila ada warga desa yang diduga melakukan suatu pelanggaran hukum kemudian diadili dalam suatu forum yang disediakanuntukitu,makawarga tersebutdikatakan "kasangkepang", "sangkepang banjar" atau "paumang banjar". Secara gramatikal, dari istilah-istilah tersebut tidak tergambar secara spesifik konsep peradilan, sebab istilah-istilahtersebut bermakna umum. Kata dasar kasangkepang adalah "sangkep", sedangkan kata dasar "paumang" adalah "paum"; keduanya mengandung arti yang sama, yaitu rapat, berapat atau melakukan rapat (Kersten, 1984:447,450,508), yang atinya pertemuan untuk membicarakan sesuatu. Dalam rapat orang dapat membicarakan apa saja, belum tentu dalam rangka menyelesaikan suatu perkara. Karena itu, tampaknya istilah "kertha desa" dapat dipertimbangkan untuk digunakan sebagai istilah lokal Bali untuk menyebut sistem peradilan adat yang hidup dan dipraktikkan dalam kesatuan-kesatuan masyarakat hukum adat desa pakraman. Penggunaan istilah ini dirasa tepat, di samping karena sudah disebut dalam beberapa awig-awig desa pakraman, secara gramatikal istilah "kertha desa" dapat mewakili gambaran konsep peradilan adat. Secara gramatikal istilah kertha berarti hakim atau pengadilan (Kersten, 1984:349); dengan di tambah dengan kata "desa", menjadilah bentukan kata "kertha desa" yang berarti "hakim desa" atau "pengadilan desa". Dengan demikian, istilah "kertha desa" sangat tepat digunakan untuk menyebut sistem peradilan adat yang hidup dan dipraktikkan dalam kesatuankesatuan masyarakat hukum adat desa pakraman di Bali. 


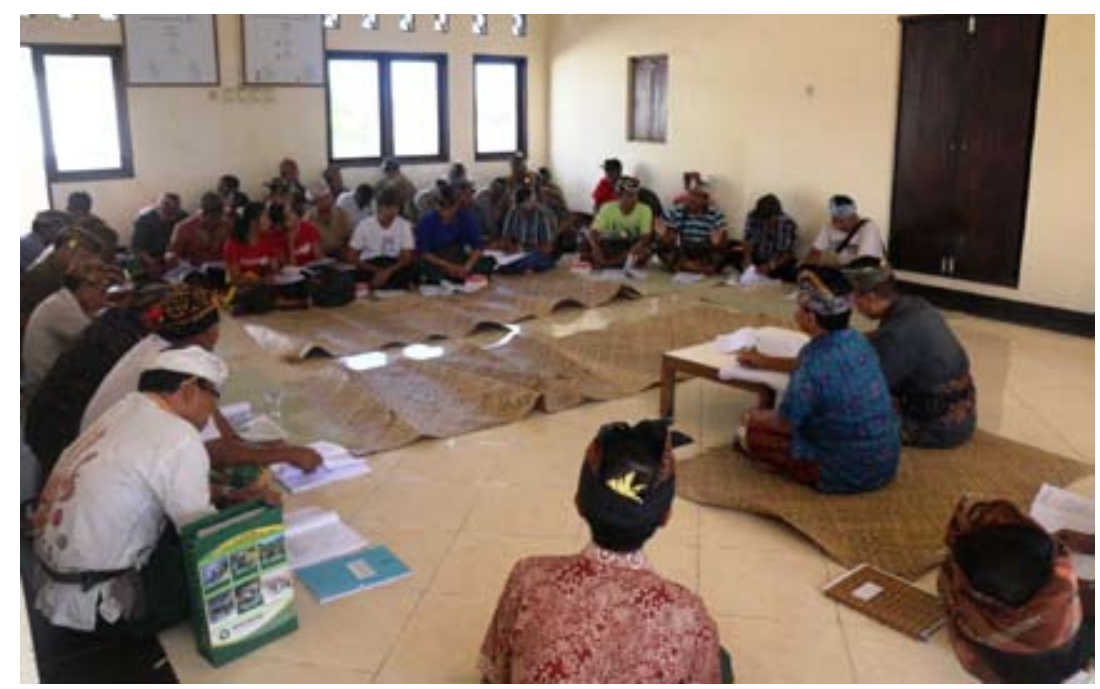

Foto 2 : Dalam paruman desa, adakalanya generasi muda juga dilibatkan (Foto Darma Putra).

\section{Kelembagaan yang melaksanakan fungsi peradilan adat}

Dari penelusuran literatur diketahui bahwa peradilan adat-di mana pun di Indonesia-berlangsung melalui suatu mekanisme tradisional dalam forum musyawarah adat ("sidang adat" atau "rapat adat") yang diberbagai tempat di Indonesia disebut dengan ungkapan khas masing-masing daerah (Anonim, 2013). Di dalam musyawarah tersebut, peranan kepala-kepala adat sangatlah penting dan menonjol, yaitu sebagai pemimpin musyawarah. Seperti pernah ditulis oleh Soepomo (1987:64), kepala-kepala adat mempunyai tugas yang sangat penting dalam penyelenggaraan hukum, meliputi aktivitas-aktivitas untuk mencegah terjadinya pelanggaran hukum ("preventieve rechtszorg") dan melakukan pembetulan hukum apabila hukum itu dilanggar ("repressieve rechtszorg"). Dalam melaksanakan tugas di bidang pembetulan hukum itulah kepala adat melaksanakan fungsi sebagai pelaksana peradilan adat.

Struktur pemerintahan adat (kepala adat) pada kesatuankesatuan masyarakat hukum adat di Indonesia sangat beragam, sehingga beragam pula lembaga yang bertugas menyelenggarakan fungsi peradilan adat di masing-masing kesatuan masyarakat hukum adat. Walaupun wilayah Bali ini kecil, dengan jumlah desa pakraman sebanyak 1480 desa (Bappeda Bali, 2013:V.1), struktur 
pemerintahan adatnya juga beragam. Pada desa-desa pakraman yang termasuk kategori desa apanage dan desa anyar (baru) pada umumnya dianut sistem pemerintahan tunggal, di mana hanya terdapat satu pejabat puncak dalam struktur pemerintahannya. Organisasi pemerintahannya lazim disebut prajuru desa yang dipimpin oleh seorang bendesa atau kelian desa. Pada desa-desa pakraman yang tergolong tipe desa baliage pada umumnya dianut sistem pemerintahan kembar, yaitu ada dua pejabat puncak dalam struktur pemerintahannya; atau sistem pemerintahan kolektif, dimana terdapat lebih dari dua pejabat puncak dalam struktur pemerintahannya. Organisasi pemerintahannya disebut paduluan (Sudantra \& Windia, 2012:29). Belakangan ini terjadi pergeseranpergeseran model sistem pemerintahan pada desa-desa yang sebelumnya murni menganut sistem pemerintahan kembar atau kolektif, mengarah pada penganutan sistem pemerintahan tunggal walaupun tanpa menghapuskan struktur kepemimpinan asli desa yang sudah diwarisi secara turun temurun.

Di samping adanya Prajuru dan/atau Paduluan di desa pakraman, di Bali juga terdapat pemerintahan desa dinas sebagai konsekuensi dari kondisi desa di Bali yang dualistis, yaitu adanya desa pakraman (desa adat) dan desa dinas dalam satu wilayah desa. Dalam kondisi desa yang dualistis ini, di satu wilayah desa berlaku pembagian urusan-urusan pemerintahan, urusan sosial keagamaan menjadi urusan dari pemerintahan desa pakraman; sedangkan urusan administrasi pemerintahan negara (seperti: urusan kartu tanda penduduk, dan lain-lain) berada pada tangan pemerintahan desa dinas.

Pemerintahan desa dinas dilakukan oleh Pemerintah Desa, yaitu Kepala Desa beserta Perangkat Desa. Di wilayah dusun, yang merupakan bagian dari desa (dinas), terdapat pejabat desa yang disebut Kepala Dusun (Klian Dinas) yang mengurus urusan pemerintahan di wilayah dusun tersebut. Di wilayah-wilayah perkotaan di mana tidak terdapat desa, urusan administrasi pemerintahan di wilayah itu diselenggarakan oleh kelurahan yang dipimpin oleh seorang Lurah; sedangkan di wilayah yang menjadi bagian dari kelurahan, yaitu lingkungan, dilakukan oleh Kepala Lingkungan (Kaling). Secara kelembagaan, tidak ada hubungan struktural antara pemerintah desa dinas/kelurahan dengan prajurul paduluan desa pakraman, walaupun di sana-sini ditemukan kasus 
terjadinya perangkapan jabatan. Walaupun tidak ada peraturan perundang-undangan yang mengatur hubungan antara pemerintah desa dinas dengan prajuru desa pakraman, namun dalam praktik keduanya menjalin hubungan yang bersifat koordinasi dan konsultatif sehingga tidak ada masalah dalam hubungan antara pemerintah desa dinas dengan prajuru desa pakraman dalam melaksanakan fungsinya masing-masing (Sudantra dan Windia, 2012:52-57).

Secara normatif dapat diketahui bahwa awig-awig desa pakraman menempatkan prajuru dalam kedudukan yang sangat penting dalam menyelesaikan perkara-perkara (wicara) yang terjadi di lingkungan desa pakraman, dimana ditentukan bahwa satu-satunya pelaksana fungsi peradilan adat di desa pakraman adalah Prajuru (Sudantra \& Sukerti, 2014:310). Namun, dalam kenyataannya Prajuru tidak bekerja sendirian dalam menyelesaikan perkara-perkara yang terjadi di desa pakraman, melainkan bekerja sama dengan pemuka-pemuka di desa, baik Paduluan (untuk desa-desa pakraman tipe bali age/desa tua) maupun dengan unsur pemerintah desa dinas. Dalam hal perkara diselesaikan pada tingkatan banjar, penyelesaian perkara dilakukan oleh prajuru banjar dibawah pimpinan Klihan Banjar bersama-sama dengan Kepala Dusun. Dari penjelasan para tua-tua desa (prajuru dan pejabat desa dinas) dapat diketahui bahwa dalam praktik penyelesaian perkara di desa pakraman, Prajuru desa pakraman dan pejabat desa dinas telah lama bersinergi dalam menyelesaikan setiap masalah yang terjadi di desa. Keduanya bahu membahu berusaha mewujudkan tujuan bersama, yaitu kasukertan desa sekala-niskala (ketertiban dan kedamaian lahir bathin di wilayah desa)

\section{Hukum yang digunakan untuk mengadili}

Dari rumusan pengertian peradilan adat dapat dipahami bahwa keberadaan peradilan adat didasarkan pada hukum adat yang berlaku pada kesatuan-kesatuan masyarakat hukum adat setempat. Dengan demikian, secara normatif hukum yang dijadikan dasar untuk mengadili setiap perkara yang ditanganinya adalah hukum adat. Dalam kesatuan masyarakat hukum adat desa pakraman, aturan-aturan hukum adat yang dijadikan pedoman dalam setiap aktivitas warganya disebut awig-awig desa pakraman. Awig-awig ini dibuat oleh anggota desa pakraman (krama desa) dalam suatu rapat 
(paruman) untuk mengatur hubungan sesama warga desa pakraman, hubungan antara warga desa pakraman dengan lingkungan alamnya, serta hubungan warga desa pakraman dengan Tuhannya. Pada awalnya, umumnya awig-awig dibuat dalam bentuk yang tidak tertulis, berupa keputusan-keputusan rapat (paruman) yang disampaikan secara lisan. Lama-kelamaan keputusan-keputusan itu dicatat seadanya oleh prajuru. Belakangan-terutama setelah diberlakukannya Peraturan Daerah Provinsi Daerah Tingkat I Bali Nomor 6 Tahun 1986-terdapat kecendrungan dari desa-desa pakraman di seluruh Bali menuliskan awig-awig-nya dalam bentuk yang tertulis dan sistematis (Sudantra, Windia \& Dyatmikawati, 2011:19)

Dalam melaksanakan tugas dan fungsi kaprajuruan-nya, Prajuru selalu berpedoman kepada ketentuan-ketentuan yang tersurat di dalam awig-awig tesebut. Akan tetapi, harus diakui bahwa awig-awig tidak mungkin dapat mengatur semua bidang kehidupan secara lengkap dan rinci. Adakalanya terdapat bidangbidang kehidupan yang tidak diatur dalam awig-awig atau pokokpokoknya sudah diatur, tetapi pengaturannya tidak lengkap. Dalam situasi seperti itu, Prajuru akan berpedoman kepada pararem dan atau adat kebiasaan yang hidup di dalam masyarakat (sima-dresta) yang pada umumnya tidak tertulis.

Pararem adalah keputusan-keputusan paruman (rapat) desa pakraman yang mempunyai kekuatan hukum mengikat sama kuat dengan awig-awig. Dilihat dari materi muatannya, pararem dapat digolongkan dalam tiga golongan, yaitu pararem panyahcah awig, pararem ngele, dan pararem panepas wicara (Sudantra, Windia \& Dyatmikawati, 2011:19; Sudantra \& Windia, 2012: 33). Pararem Panyahcah Awig, adalah golongan pararem yang memuat ketentuan lebih rinci dari ketentuan yang pokok-pokoknya sudah diatur dalam awig-awig. Dapat dikatakan bahwa Pararem Panyahcah Awig ini sebagai aturan pelaksaaan dari awig-awig. Misalnya, dalam awigawig ditentukan bahwa: "Swadharmaning krama desa pakraman.... patut keni ayah-ayahan lan papeson sajangkepnyane manut pararem" (Anggota desa pakraman wajib melakukan kewajiban fisik dan urunan sesuai keputusan rapat desa).

Dengan pengaturan yang masih umum seperti itu tentu saja ketentuan awig-awig tersebut belum dapat dijalankan, karena tidak secara jelas dan rinci menyebut bentuk iuran yang menjadi 
kewajiban dari kerama desa, apakah berupa materi (misalnya: beras, dan lain-lain) ataukah uang, dan berapa pula nilai atau bedsarannya. Agar ketentuan tersebut operasional, maka masih perlu dibuatkan dibuatkah ketentuan yang lebih jelas dan rinci mengenai bentuk atau pun besaran iuran dalam sebuah pararem. Misalnya, dalam pararem ditentukan iuran tersebut berupa uang dengan nilai tertentu. Golongan pararem yang kedua adalah Pararem Ngele atau Pararem Lepas, yang memuat ketentuan-ketentuan hukum adat (dresta) atau kesepakatan-kesepakatan yang diputuskan dalam paruman desa, di mana normanya sama sekali tidak diatur dalam awig-awig tertulis yang sudah ada. Materi muatannya itu, bisa jadi adalah hukum adat yang telah ada dan diwarisi secara turun temurun tetapi tercecer dan tidak dimuat dalam awig-awig tertulis; atau norma yang dituangkan adalah norma hukum baru yang disepakati dan diputuskan dalam paruman yang sengaja diadakan untuk menghadapi hal-hal yang sedang terjadi atau pun untuk mengantisipasi perkembangan di masa depan. Misalnya, ketika desa pakraman merasa terancam oleh semakin masifnya pemindahtanganan tanah (jual-beli) di wilayah desa pakraman kepada pihak luar desa pakraman, kemudian desa pakraman membuat pararem untuk mengantisipasi atau membatasi terjadinya pemindahtanganan tanah di wilayahnya. Golongan ketiga adalah Pararem Panepas Wicara yang berisi keputusan paruman tentang perkara konkrit yang pernah diselesaikan oleh desa pakraman. Peristiwa konkret tersebut, mungkin tidak diatur dalam awig-awig, misalnya terjadi perkawinan antara pasangan sejenis, dan lain-lain. Desa pakraman kemudian menyelesaikan perkara tersebut dalam suatu paruman (peradilan adat) dan keputusannya dituangkan dalam pararem. Keputusan tersebut dapat dikwalifikasikan sebagai Pararem Panepas Wicara, semacam yurisprudensi dalam sistem hukum negara, yang dapat dijadikan pedoman oleh Prajuru apabila di lain hari menghadapi perkara yang sama atau serupa.

Dalam pelaksanaan peradilan adat, ketentuan-ketentuan di atas dijadikan dasar oleh Prajuru dalam menyelesaikan perkaraperkara yang dihadapinya. Intinya, hukum yang dijadikan dasar oleh Prajuru selaku Kertha Desa dalam memeriksa dan mengadili perkara adalah hukum adat Bali sebagaimana yang tertuang dalam awig-awig dan atau pararem desa pakraman. Dalam hal tidak ada pegangan dalam awig-awig/pararem tertulis, Prajuru berpedoman 
kepada adat kebiasaan (sima-dresta) setempat yang sudah berlaku dan diikuti secara turun temurun.

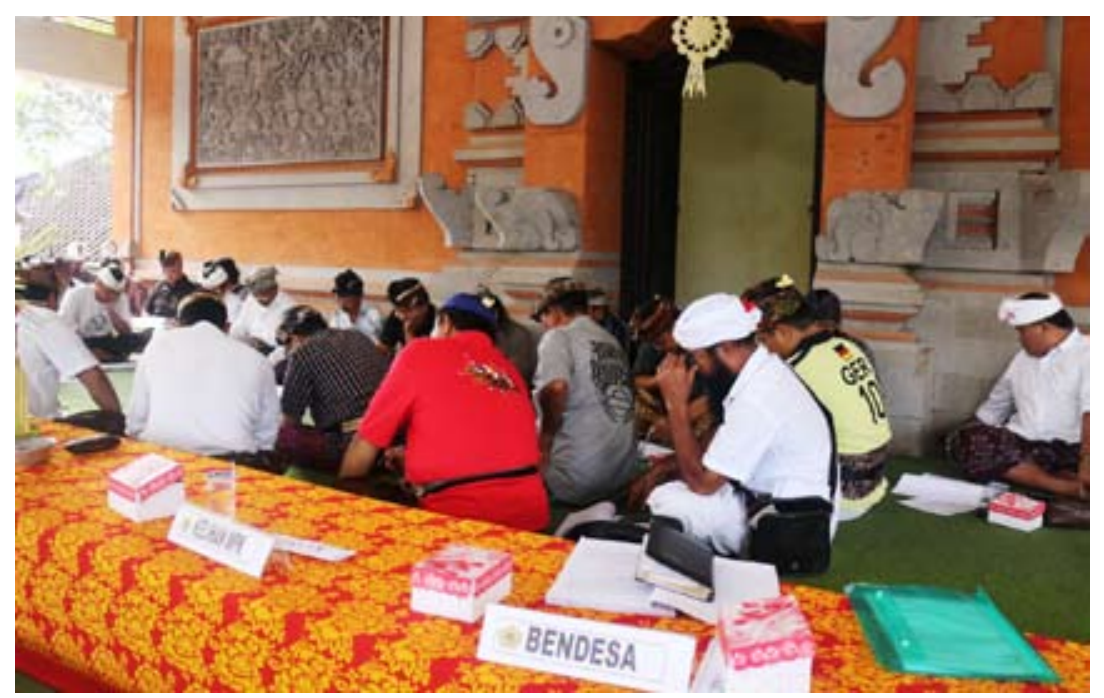

Foto 3. Bendesa dan prajuru desa aktif dalam rapat desa untuk menemukan solusi bersama untuk menjaga ketertiban dan ketentraman desa (Foto Darma Putra).

\section{Kompetensi peradilan adat}

Kompetensi peradilan menyangkut kewenangan suatu lembaga peradilan untuk mengadili, baik menyangkut wilayah hukumnya (kompetensi relatif) maupun menyangkut obyek, materi atau pokok perkara (kompetensi absolut). Mengacu kepada Pasal 51 Undangundang Nomor 21 Tahun 2001 dapat diketahui kompetensi relatif dan kompetensi absolut peradilan adat, yaitu:

(1) peradilan adat adalah peradilan perdamaian di lingkungan masyarakat hukum adat;

(2) peradilan adat mempunyai kewenangan memeriksa dan mengadili sengketa perdata adat dan perkara pidana;

(3) peradilanadatberwenang mengadili perkara-perkaradiantara para warga masyarakat hukum adat yang bersangkutan.

Dengan demikian, berdasarkan ketentuan Pasal 51 Undangundang Nomor 21 Tahun 2001, kompetensi relatif peradilan adat meliputi lingkungan wilayah kesatuan masyarakat hukum adat yang bersangkutan, sedangkan kompetensi absolutnya meliputi 
perkara-perkara adat, baik yang bersifat perdata (sengketa) maupun pidana.

Uraian di atas menunjukkan bahwa pada dasarnya peradilan adat berlaku internal, yaitu hanya berwenang mengadili perkara antara warga kesatuan masyarakat hukum adat yang bersangkutan. Tetapi, dewasa ini wilayah kesatuan masyarakat hukum adat bukanlah wilayah yang tertutup atau terisolasi dari daerah lain. Dalam wilayah suatu kesatuan masyarakat hukum adat bisa saja terdapat warga luar kesatuan yang berada di wilayah itu karena suatu keperluan. Demikian juga, interaksi warga masyarakat adat dewasa ini tidak lagi hanya sebatas pergaulan diantara sesama warga kesatuan masyarakat hukum adat saja, bahkan dapat dikatakan bahwa terjadinya interaksi antara warga kesatuan masyarakat hukum adat dengan warga luar kesatuan adalah suatu keniscayaan.

Dalam kondisi demikian, tidak tertutup kemungkinan terjadinya masalah-masalah hukum antara orang-orang luar kesatuan masyarakat hukum adat dengan masyararakat adat setempat baik sebagai kesatuan ataupun perorangan. Sesuai perkembangan masyarakat yang semakin terbuka dalam interaksinya dengan masyarakat luar, praktik peradilan adat di beberapa daerah di Indonesia juga menyelesaikan perkara-perkara antara warga kesatuan masyarakat hukum adat dengan warga luar kesatuan masyarakat hukum adat yang bersangkutan. Di Papua, praktik semacam itu diakui berdasarkan peraturan daerah setempat (Sudantra, 2016:117).

Berkaitan dengan kompetensi absolut peradilan adat, ketentuan Pasal 51 Undang-undang Nomor 21 Tahun 2001 tampaknya sesuai dengan penjelasan Soepomo (1987:26) bahwa hukum adat tidak mendikotomikan antara perkara perdata dan perkara pidana. Menurut Soepomo, kepala adat sebagai pemegang kekuasaan penyelenggaran hukum dalamkesatuanhukumbertugas melakukan pembetulan hukum apabila hukum itu dilanggar, sehingga ia wajib menyelesaikan semua perkara yang terjadi di lingkungan masyarakat hukum adat tanpa memperdulikan apakah perkara tersebut termasuk dalam ranah perdata atau pidana.

Di Bali, berdasarkan Peraturan Daerah Nomor 3 Tahun 2001 kewenangan desa pakraman dalam menyelesaikan perkara dibatasi, yaitu hanya menyelesaikan perkara-perkara yang berupa sengketa. 
Pasal 6 Peraturan Daerah tersebut menentukan bahwa "Desa Pakraman mempunyai wewenang menyelesaikan sengketa adat dan agama dalam lingkungan wilayahnya dengan tetap membina kerukunan dan toleransi antarkrama desa sesuai dengan awig-awig dan adat kebiasaan setempat". Akan tetapi, dari hasil penelitian terhadap awig-awig desa pakraman yang dilakukan oleh Sudantra \& Sukerti (2014:311) diketahui bahwa awig-awig desa pakraman tidak mengadakan pembatasan seperti itu. Di dalam awig-awig desa pakraman sudah ditentukan bahwa keseluruhan perkara (wicara) yang terjadi dalam masyarakat harus diselesaikan oleh prajuru, baik perkara yang dikwalifikasikan sebagai pelanggaran hukum maupun sengketa.

Dikonfirmasi secara empiris, ketentuan awig-awig tersebut di atas benar-benar diimplementasikan dalam praktik penyelesaian perkara di wilayah desa pakraman. Dalam kenyataan, prajuru selalu menangani setiap perkara yang diajukan kepadanya, tanpa membedakan apakah perkara itu berupa sengketa ataupun pelanggaran hukum. Hanya saja, dalam hal terjadi sengketa, prajuru lebih bersifat pasif karena baru bertindak setelah adanya laporan (pasadok) dari pihak yang bersengketa; sedangkan dalam hal terjadi pelanggaran hukum prajuru bersifat aktif di mana ia langsung bertindak setelah mengetahui terjadinya pelanggaran tanpa menunggu adanya laporan atau pengaduan. Kenyataan juga membuktikan kebenaran pernyataan Cantika (2010:105) bahwa perkara-perkara yang terjadi di wilayah desa pakraman beragam kwalifikasinya, meliputi perkara adat murni, yaitu perkara yang semata-mata hanya berupa sengketa adat atau pelanggaran terhadap hukum adat; perkara-perkara campuran yaitu sengketa adat yang sekaligus sengketa keperdataan pada umumnya ataupun pelanggaran adat sekaligus pelanggaran terhadap hukum negara; dan perkara-perkara non-adat, yaitu perkara yang sama sekali tidak ada kaitannya dengan masalah adat. Dalam praktik, ternyata prajuru tidak hanya menyelesaikan perkara-perkara adat murni, melainkan juga menyelesaikan perkara-perkara campuran, bahkan dalam batas-batas tertentu juga menyelesaikan perkara non adat. Dilihat dari subjek perkara, ternyata prajuru tidak hanya menyelesaikan perkara-perkara yang terjadi diantara warga anggota kesatuan (krama desa) tetapi juga menyelesaikan perkaraperkara yang dilakukan penduduk pendatang di wilayah desa 
pakraman (krama tamiu atau tamiu)

Bentuk-bentuk perkara berupa sengketa yang sering ditangani oleh Prajuru, misalnya sengketa utang-piutang, sengketa batas pekarangan, perceraian, dan lain-lain; sedangkan perkaraperkara yang berupa pelanggaran hukum, pada umumnya berupa tindakan-tindakan yang melanggar awig-awig desa pakraman, seperti warga desa (krama desa) tidak melaksanakan kewajiban (ayahan) atau penduduk pendatang (krama tamiu atau tamiu) tidak melaporkan kehadirannya di desa pakraman, dan lain-lain. Tidak jarang juga, prajuru menangani perkara-perkara yang menurut hukum negara dikategorikan sebagai tindak pidana ringan, seperti penghinaan, penganiaayan ringan, dan lain-lain.

\section{Mekanisme kerja dari peradilan adat}

Hukum adat menyediakan mekanisme-mekanisme penyelesaian perkara yang lazim digunakan dalam masyarakat hukum adat. Mohamad Koesnoe (1979:49), pernah menyebutkan dua ajaran dalam penyelesaian masalah secara hukum adat, yaitu: (1) ajaran menyelesaikan dan (2) ajaran memutus. Dalam menghadapi masalah melalui "ajaran menyelesaikan", penggarapannya diusahakan sedemikian rupa sehingga para pihak tetap dapat meneruskan kehidupan bersama sebagaimana sebelum terjadinya masalah. Penyelesaian dengan menggunakan ajaran ini mengarah kepada upaya mengembalikan kedamaian dan keharmonisan hubungan-hubungan yang telah ada sebelumnya, baik hubungan antara para pihak yang bermasalah maupun hubungan-hubungan lain dalam masyarakat. Oleh karena itu, dalam menghadapi masalah dengan menggunakan ajaran menyelesaikan ini sangat dikedepankan asas rukun dan laras dengan menggunakan caracara musyawarah untuk mencapai mufakat. Dengan model penyelesaian ini, perasaan-perasaan, kepentingan-kepentingan para pihak dapat diakomodasi dengan sewajarnya sehingga lebih mudah mencapai perdamaian.

Tetapi Koesnoe menyadari bahwa tidak semua masalah dapat diselesaikan dengan ajaran menyelesaikan, misalnya terhadap masalah-masalah yang membahayakan kehidupan bersama sehingga perlu dilakukan suatu langkah yang segera, tegas dan jelas. Tidak jarang juga, salah satu pihak yang bermasalah tidak bersedia melakukan perdamaian, sehingga perkara tersebut harus 
diselesaikan dengan menerapkan ajaran memutus. Penyelesaian melalui ajaran memutus lebih menekankan pada hak-hak yang diterima dan kewajiban-kewajiban yang harus dilakukan para pihak tanpa terlalu mempertimbangkan apakah hubungan para pihak sebelum terjadinya masalah masih bisa berlanjut atau tidak.

Walaupun awig-awig desa pakraman tidak menegaskan secara spesifik model penyelesaian mana yang dianut atau lebih diutamakan, namun hasil penelitian yang dilakukan oleh Sudantra \& Sukerti (2014:313) telah menunjukkan bahwa secara tersirat awigawig-awig desa pakraman menganut kedua model penyelesaian perkara yang dikemukakan oleh Koesnoe tersebut. Hasil penelitian lapanganjuga membuktikanbahwa dua model penyelesaian perkara tersebut memang dilakoni dan dipraktikkan dalam kehidupan kesatuan-kesatuan masyarakat hukum adat desa pakraman di Bali. Dalam praktik, ketika Prajuru menghadapi masalah-masalah yang terjadi di lingkungan desa pakraman, pertama-tama Prajuru senantiasa berusaha menyelesaikan masalah tersebut dengan caracara kekeluargaan yang mengedepankan asas musyawarah untuk mencapai mufakat, sehingga suasana damai diantara para pihak maupun masyarakat dapat terjaga. Akan tetapi, apabila cara-cara ini gagal, Prajuru tidak sungkan mengambil sikap dengan memberi keputusan sesuai otoritasnya.

Dalam proses penyelesaian suatu perkara, langkah pertama yang biasanya dilakukan oleh Prajuru setelah mengetahui atau menerima pasadok (laporan/pengaduan) terjadinya suatu masalah adalah melakukan penyelidikan terhadap peristiwanya dengan menggelar suatu paruman prajuru. Pada umumnya, paruman diselenggarakan di balai pertemuan milik banjar/desa pakraman (Balai Banjar atau Balai Desa). Dalam paruman tersebut, pihak yang diduga melakukan pelanggaran atau para pihak yang bersengketa dipanggil untuk didengar keterangannya. Setelah itu, dilakukan pembicaraan secara musyawarah mengenai duduk perkaranya serta bentuk-bentuk penyelesaiannya yang dapat diambil. Dalam pembicaraan tersebut, pihak yang diduga melakukan pelanggaran atau para pihak yang bersengketa diberi kesempatan untuk menyampaikan duduk perkara menurut versinya masingmasing, perasaan-perasaannya, pikiran-pikirannya, dan harapanharapannya mengenai bentuk penyelesaian dari masalah yang dihadapinya. Peserta Paruman Prajuru juga didengar pendapat 
serta saran-sarannya. Semua itu akan menjadi pertimbangan dalam pengambilan keputusan.

Dalam hal perkara tersebut berupa sengketa, biasanya Prajuru berusaha mendamaikan para pihak yang bersengketa dengan mengupayakan terjadinya kesepakatan antara para pihak. Apabila para pihak sepakat untuk berdamai, maka Prajuru hanya mengukuhkan bahwa perkara sudah diselesaikan secara perdamaian. Kadang-kadang kesepakatan perdamaian tersebut cukup dilakukan secara lisan oleh para pihak dihadapan Paruman, tapi adakalanya dibuat secara tertulis dengan ditandatangani oleh para pihak serta Kelihan Banjar dan atau Bendesa/Klihan Desa sebagai saksi mewakili Prajuru. Apabila kesepakatan tidak dapat dicapai oleh para pihak, maka Prajuru mengambil sikap menentukan keputusannya sendiri dengan berpedoman kepada awig-awig atau pararem desa pakraman.

Dalam mengambil keputusan terhadap perkara yang menyangkut pelanggaran hukum, Prajuru mempertimbangkan berat ringannya kesalahan pelaku dan atas dasar itu ditentukan sanksi (pamidanda) yang dijatuhkan kepada pelaku. Dalam awigawig, bentuk-bentuk pamidanda dikualifikasikan dalam tiga golongan, yaitu: (1) artha danda (sanksi berupa materi), mulai dari dedosan (denda uang atau barang), panikel (kelipatan denda apabila dedosan tidak dibayar sesuai waktu yang ditentukan), dan yang paling berat adalah karampag (dirampas hartanya untuk membayar hutang denda); (2) jiwa danda, yaitu sanksi yang menyangkut jiwa dan fisik, mulai dari yang paling ringan, yaitu kaglemekin (ditegur), nunas pangampura (meminta maaf), kasepekang (dikucilkan dan tidak mendapat pelayanan adat), dan yang paling berat kanorayang makrama (dipecat sebagai anggota desa pakraman); dan (3) panyangaskara danda (sanksi berupa kewajiban melakukan upacara keagamaan untuk mengembalikan keseimbangan magis), dari yang paling ringan (nista), sedang (madya), atau utama (besar), seperti melakukan upacara prayascita dan macaru. Rumusan bentuk-bentuk sanksi yang disebutkan dalam awig-awig belum operasional, karena hanya menyebutkan bentuk-bentuk sanksi, tanpa menegaskan untuk pelanggaran-pelanggaran apa saja sanksi tersebut diterapkan. Oleh karena itu, Paruman Prajuru biasanya memusyawarahkan terlebih dahulu bentuk sanksi yang dijatuhkan kepada pihak yang telah melakukan pelanggaran hukum. 


\section{Simpulan}

Berdasarkan uraian di atas, akhirnya dapat disimpulkan bahwa peradilan adat adalah suatu fakta empiris, yang nyata-nyata ada, hidup dan dipraktikkan dalam kehidupan dari kesatuan-kesatuan masyarakat hukum adat desa pakraman di Bali. Kelembagaan yang melaksanakan fungsi peradilan adat di desa pakraman adalah Prajuru, yang dilakukan melalui suatu forum musyawarah (Paruman Prajuru) dihadiri elemen kelembagaan lain yang ada di desa pakraman, yaitu Paduluan (untuk desa baliage/desa tua) dan atau pejabat pemerintahan desa dinas (Kepala Dusun/Kepala Desa) yang mewilayahi atau berada di wilayah desa pakraman yang bersangkutan. Mengingat Paruman Prajuru, sesungguhnya mempunyai fungsi lain selain fungsi peradilan, maka istilah lokal yang tepat digunakan untuk menyebut paruman prajuru dalam fungsinya menyelenggarakan peradilan di desa pakraman adalah Kertha Desa, yang artinya pengadilan atau hakim desa.

Hasil penelitian juga menunjukkan bahwa peradilan adat (Kertha Desa) memeriksa, mengadili, dan memutuskan setiap perkara yang diajukan kepadanya berdasarkan pada hukum adat Bali, sebagaimana terwujud dalam awig-awig desa pakraman, pararem, dan/atau sima-dresta. Perkara-perkara yang menjadi kompetensi peradilan adat meliputi semua perkara yang terjadi di wilayah desa pakraman dan diajukan penyelesaiannya kepada Prajuru selaku Kertha Desa. Perkara-perkara tersebut dapat berupa sengketa atau pelanggaran hukum, baik yang tergolong sebagai perkara adat murni, perkara campuran maupun perkara nonadat.

Dalam menghadapi perkara-perkara yang terjadi di desa pakraman, peradilan adat memberlakukan mekanisme yang berbeda antara sengketa dan pelanggaran hukum. Terhadap perkara-perkara yang berupa sengketa, Prajuru bersifat pasif, yaitu menunggu adanya pasadok (laporan/pengaduan) dari pihakpihak yang berperkara; sedangkan dalam hal perkara tersebut berupa pelanggaran hukum, seperti kacorahan (kejahatan) dan tindakan-tindakan lain yang melanggar awig-awig atau pararem, Prajuru bersifat aktif, yaitu langsung bertindak setelah mengetahui terjadinya pelanggaran tersebut. Penyelenggaraan peradilan (Paruman Prajuru) pada umumnya dilakukan di tempat pertemuan milik desa (Balai Banjar atau Balai Desa Pakraman). Para pihak yang 
berperkara di panggil dan di dengar keterangannya dihadapan peserta Paruman Prajuru, kemudian dibicarakan mengenai duduk perkaranya, kepentingan-kepentingan yang terkait, dan solusisolusi penyelesaiannya, kemudian diambil keputusan terbaik secara musyawarah mufakat sehingga diharapkan dapat diterima semua pihak secara lapang dada.

\section{Ucapan terima kasih}

Karya tulis ini dapat hadir di hadapan pembaca adalah berkat bantuan dari berbagai pihak yang tidak dapat penulis sebutkan satu persatu. Secara khusus, kami -para penulis - menyampaikan penghargaan dan ucapan terima kasih kepada Prof. Dr. I Made Arya Utama, SH, M.Hum., Dekan Fakultas Hukum Universitas Udayana, yang telah mengizinkan para penulis mengerjakan karya tulis ini disela-sela kesibukan melaksanakan tugas pengajaran. Tidak lupa pula kami mengucapkan terimakasih kepada Prof. Dr. Ir. I Nyoman Gde Antara, MEng, Ketua Lembaga Penelitian dan Pengabdian Kepada Masyarakat Universitas Udayana, yang telah memfasilitasi pendanaan penelitian yang menjadi dasar pembuatan karya tulis ini. Semoga amal baik para budiman tersebut mendapat pahala yang semestinya dari Ida Sanghyang Widi Wasa, Tuhan Yang Maha Esa.

\section{Daftar pustaka}

Anonim. 2003. Sistem Peradilan Adat dan Lokal di Indonesia: Peluang dan Tantangan, Jakarta: Aliansi Masyarakat Adat Nusantara (AMAN)-Partnership for Governance Reform.

Bappeda (Badan Perencanaan Pembangunan Daerah) Pemerintah Provinsi Bali, 2013, Data Bali Membangun 2012

Çantika, I Wayan Koti. 2010, "Tatacara Penerapan Pamidanda", dalam: I Ketut Sudantra dan AA Gede Oka Parwata (ed), Wicara lam Pamidanda, Pemberdayaan Desa Pakraman dalam Penyelesaian Perkara di Luar Pengadilan, hlm. 93 - 113, Denpasar: Udayana University Press.

Dewan Perwakilan Rakyat Republik Indonesia, Prolegnas Prioritas (2017), tersedia di URL: http://www.dpr.go.id/uu/prolegnas. Diakses: 15 Februari 2017.

Jamin, Mohammad et.al., 2014. "The Shifting Politics Of Law In The 
Recognition Of Customary Court In Papua Following The Enactment Of Special Autonomy Act", US-China Law Review, Vol 11 No 4, April 2014, p. 367 - 388

Kersten S.V.D J., 1984. Bahasa Bali, Ende-Flores: Penerbit Nusa Indah.

Koesnoe Moh.,1979. Catatan-catatan Terhadap Hukum Adat Dewasa Ini, Airlangga University Press.

Krisifu, Hendrik HJ. 2014. "Peradilan Adat di Papua", Jurnal Hukum dan Masyarakat, Vol. 13 No 3, Agustus 2014, h. 12 - 25.

Soepomo, R.,1987, Bab-bab tenang Hukum Adat, Jakarta: Pradnya Paramita.

Sudantra, I Ketut \& Wayan P. Windia, 2012, Sesana Prajuru Desa Tata Laksana Pimpinan Desa Adat di Bali, Denpasar: Udayana University Press.

Sudantra, I Ketut, Wayan P. Windia \& Putu Dyatmikawati. 2011. Penuntun Penyuratan Awig-awig, Udayana University Press bekerjasama dengan Bali Santi, Denpasar.

Sudantra, I.K. dan Sukerti. 2014. "Pengaturan Peradilan Adat dalam Awig-awig Desa Pakraman: Studi Pendahuluan tentang Eksistensi Peradilan Adat dalam Kesatuan Masyarakat Hukum Adat Desa Pakraman", Jurnal Magister Hukum Udayana, Vol. 3 (Vol 6) No. 2., h.310-326

Sudantra, I.K. 2016. Pengakuan Peradilan Adat dalam Politik Hukum Kekuasaan Kehakiman, Denpasar: Swasta Nulus.

Tody Sasmitha Jiwa Utama dan Sandra Dini Febri Aristya. 2015. "Kajian tentang Relevansi Peradilan Adat Terhadap Sistem Peradilan Perdata Indonesia“, Mimbar Hukum, Volume 27 No 1 Februari 2015, h. $57-67$. 